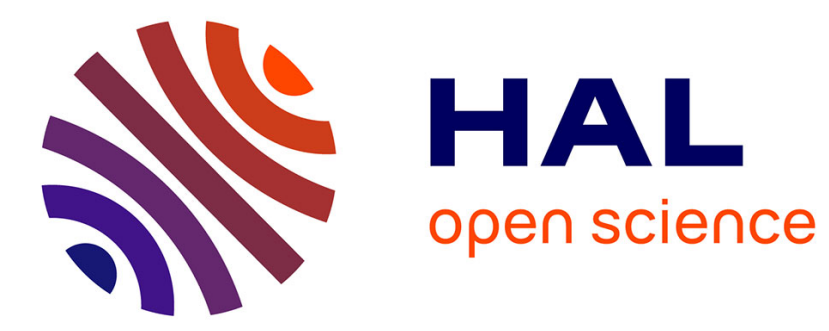

\title{
Comparative study of regulations, codes and standards and practices on hydrogen fuelling stations
}

\author{
Sylvaine Pique, Benno Weinberger, Valérie de Dianous, Bruno Debray
}

\section{To cite this version:}

Sylvaine Pique, Benno Weinberger, Valérie de Dianous, Bruno Debray. Comparative study of regulations, codes and standards and practices on hydrogen fuelling stations. International Journal of Hydrogen Energy, 2017, 42 (11), pp.7429-7439. 10.1016/j.ijhydene.2016.02.158 . ineris-01862942

HAL Id: ineris-01862942

https://hal-ineris.archives-ouvertes.fr/ineris-01862942

Submitted on 28 Aug 2018

HAL is a multi-disciplinary open access archive for the deposit and dissemination of scientific research documents, whether they are published or not. The documents may come from teaching and research institutions in France or abroad, or from public or private research centers.
L'archive ouverte pluridisciplinaire HAL, est destinée au dépôt et à la diffusion de documents scientifiques de niveau recherche, publiés ou non, émanant des établissements d'enseignement et de recherche français ou étrangers, des laboratoires publics ou privés. 


\title{
COMPARATIVE STUDY OF REGULATIONS, CODES AND STANDARDS AND PRACTICES ON HYDROGEN FUELLING STATIONS
}

\author{
S. PIQUE, B. WEINBERGER, V. DE-DIANOUS, B. DEBRAY
}

Corresponding author: benno.weinberger@ineris.fr

INERIS, Parc technologique ALATA BP 2, 60550 Verneuil en Halatte, France

\section{ABSTRACT}

This work deals with a comparative study of regulations, codes and standards for hydrogen fuelling station dedicated for light duty land vehicles in the following countries: United States (California), United Kingdom, Italy, Germany, Canada, Sweden, Norway, Denmark and Spain.

The following technical components of a hydrogen fuelling station are included in the scope of the study: the hydrogen storage systems (cryogenic or compressed gases) and buffer storage, the compressor stations, the high pressure buffer storage, the cooling systems for hydrogen, the dispensing equipments and the dispensing area. The hydride storage, the pipelines, on site production and the hydrogen vehicle have been excluded.

The analysis, performed in September 2014 in a report from INERIS DRA-14-14153206227C BENCHMARK STATIONS-SERVICE HYDROGENE, is based on documents collected by bibliographic review and information obtained through a questionnaire sent to authorities and IA HySafe ${ }^{1}$ members in the above mentioned countries.

This paper gives a synthesis of the regulations and on permitting process in the different studied countries (including the new European Directive on the deployment of alternative fuels infrastructure in Europe ${ }^{2}$ ), it develops the required safety barriers in the different parts of a fuelling station and specially for the dispensing area, gives an overview of the different approaches for safety distances and processes to obtain licenses to operate. 


\section{Introduction}

\subsection{Context of the study}

Alternative fuels like hydrogen have several environmental benefits; anyway they have to prove their economic interest and technical maturity while the regulatory framework is still missing in many countries and is still far away to be harmonized.

Research and technological developments have led to successful demonstrations of alternative fuel solutions for all transport modes. In relation to this topic, INERIS, performed a comparative study of regulations, professional guides and applicable standards in other countries $^{3}$. The objective was to highlight the practices in other countries in the field of prevention or limitation of major accidents in hydrogen fuelling station.

The aim was to answer the following questions:

- What are the regulations and best practices regarding the design, setting up and operating of hydrogen fuelling stations? In particular:

- Which safety barriers are required or recommended for hydrogen fuelling stations to prevent or reduce the effects of fires or explosions?

- What are the safety distances of the hydrogen fuelling stations from other installations?

- Are there different processes for obtaining a license to operate a hydrogen fuelling station? Which governmental organization or private agency is responsible for the enforcement of the regulations?

\subsection{Studied countries}

The benchmark was targeted on countries that have already hydrogen fuelling stations and associated regulations: the USA (California), the United Kingdom, Germany, Italy, Canada, Sweden, Norway, Denmark and Spain. France was not targeted, as far as the study was realized for the French administration previewing to establish a regulatory frame in the future. Asia could not be included due to a lack of information.

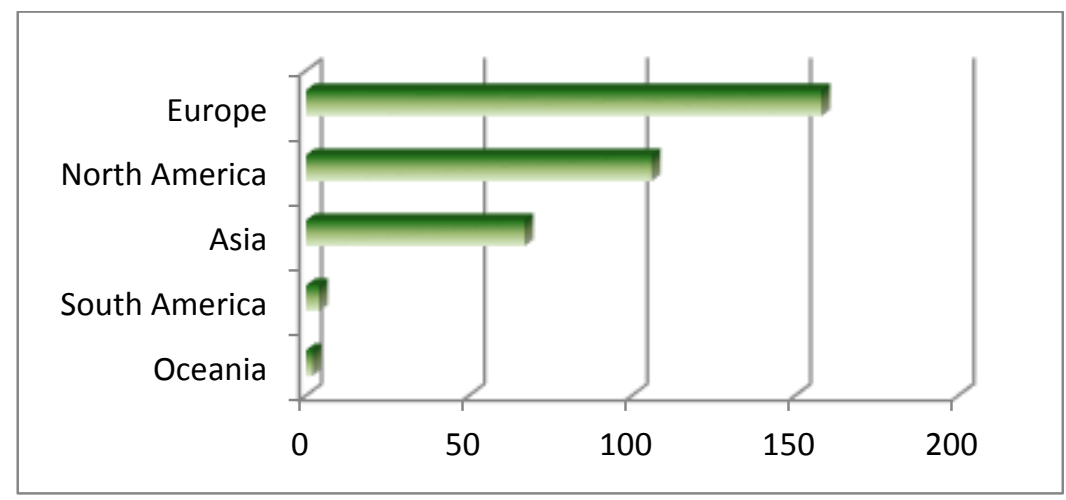

Figure 1 : Distribution of hydrogen fuelling stations by continent (March 2015) ${ }^{4}$ 


\subsection{Purpose of this study}

Hydrogen is a universal energy carrier and can be produced from primary energy sources as well as from renewable energies. As transport fuel it could integrate renewable energies in the transport sector, reduce $\mathrm{CO}_{2}$ emissions and micro particles.

In order to establish a regulatory framework for the distribution of hydrogen, the purpose of the study were to:

- enhance safety hydrogen knowledge on fuelling station technologies,

- identify the key legislations,

- highlight main safety barriers.

The report will be used by French competent authorities. It will also be made available to the public to inform stakeholders and increase public confidence.

\subsection{Scope of the study}

The study covers the delivery of hydrogen, its storage in the station until the distribution zone.

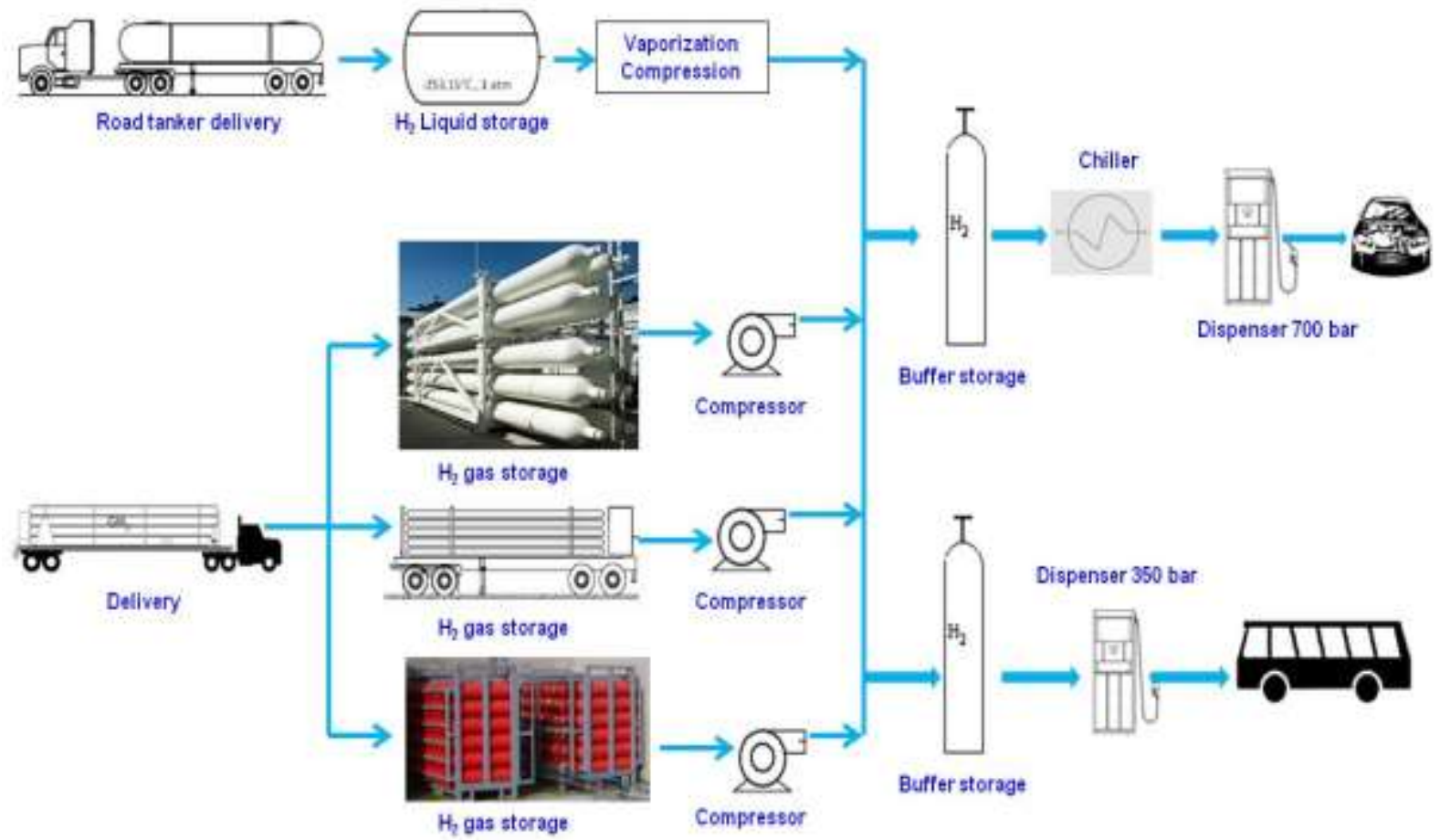

Figure 2: The different types of configurations of hydrogen fuelling stations

The onsite production of hydrogen, storage in hydride form and the delivery by pipeline or trucks are excluded. Here it should be noted that there is a clear difference between "hydrogen storage" previewed for long and midterm storage almost limited to 300 bar and "buffer storage" used for high pressure storage up to 1100 bar in particular covered by the committee draft ISO CD $19884^{5}$ actually in preparation.

\section{Methodology}

In order to identify the key legislation, INERIS conducted in a first part a bibliographic search to identify regulatory documents, standards and professional guides. 
To complete the information, a questionnaire was sent to around 60 contacts:

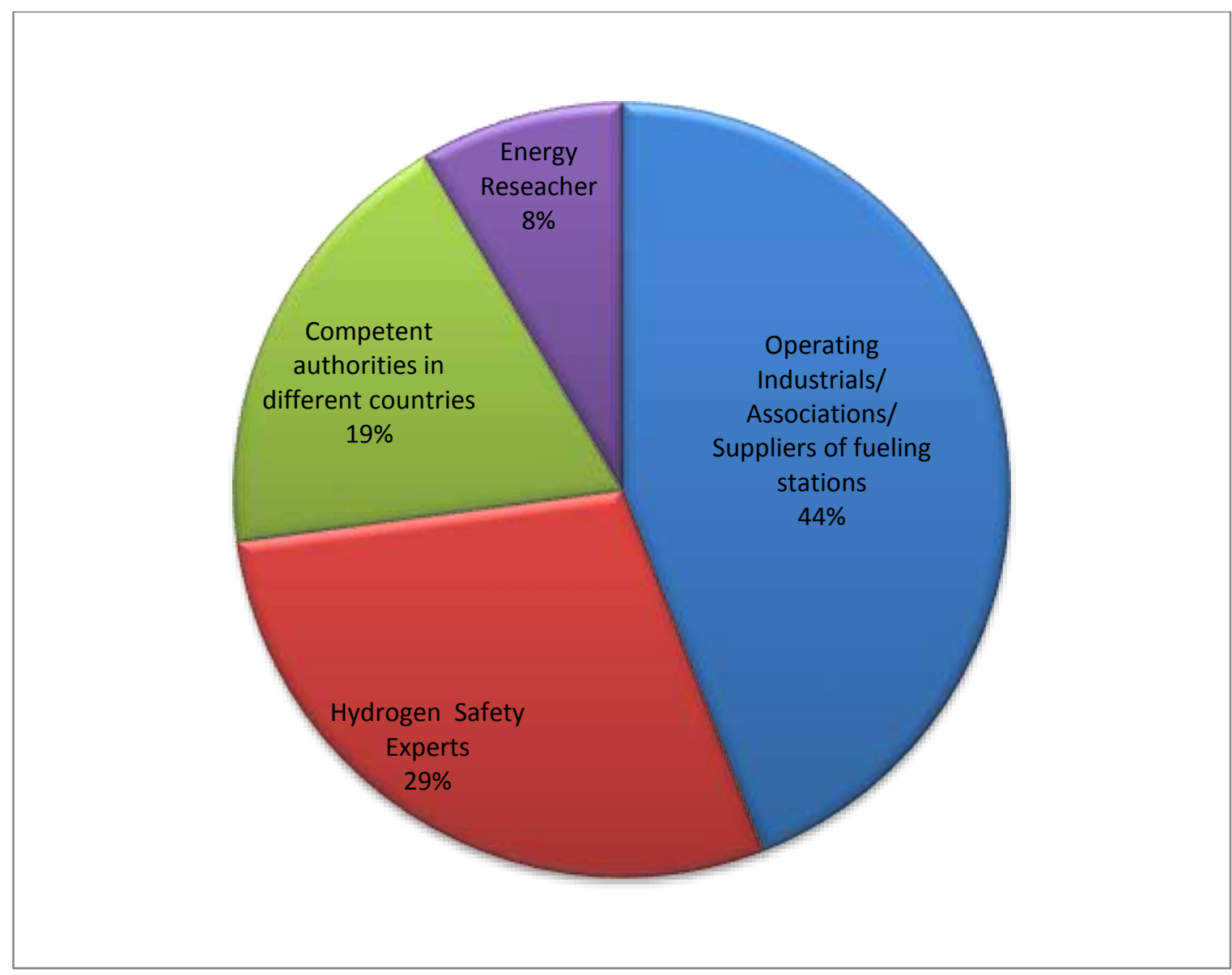

Figure 3 : Percentage of contacts by activities

The questionnaire, detailed in Table 1, was focused on:

- the identification of main regulations and best practices in each country related to hydrogen fuelling stations;

- reviewing the safety barriers required for fuelling stations;

- lessons learned on the technology in terms of safety. 


\section{Main questions}

1 In your country, what are the existing regulations regarding hydrogen fuelling stations?

2 Are there specific standards or best practices used for hydrogen fuelling stations regarding technical aspects or the qualification of employees...?

3 Which government department or private agency is responsible for the enforcement of the regulations?

Are there any known safety distances for the localization of the hydrogen fuelling
stations (distances to: other hazardous installations, hospitals/schools,
neighbourhood...)?
neighbourhood...)?

$5 \quad$ Which safety barriers are required or recommended for hydrogen fuelling stations to prevent or reduce the effects of fires or explosions?

Does the legislation give technical requirements (e.g. use of cryogenic instead of
compressed gases or inverse, underground storage, type of compressors, maximum
design pressure, material requirements e.g. 316 stainless steel etc...)?

\section{Supplementary questions}

1 In your country, are there regulations in progress regarding hydrogen fuelling stations?

2 Which regulation is required for the hydrogen fuelling stations? Labour regulation? Environment Code? Town planning code?

Are there different processes for obtaining a license to implement hydrogen fuelling 3 stations (e.g. just notification, authorization, demonstration that risk is acceptable...)? Does it depend on quantity stored or mass flow of hydrogen?

$4 \quad$ Are there specific regulations or requirements regarding hydrogen fuelling stations without service personnel?

5 Are there different regulations or requirements regarding hydrogen fuelling stations for buses and cars?

In your country do you record accidents regarding hydrogen fuelling stations? If

6 yes, do you identify the root causes? Which measures have been taken following accidents? Are these incidents/accidents documented into any database and if possible could you forward us these information's if they are public?

Table 1 : Content of the questionnaire 
In total we received 12 answers.
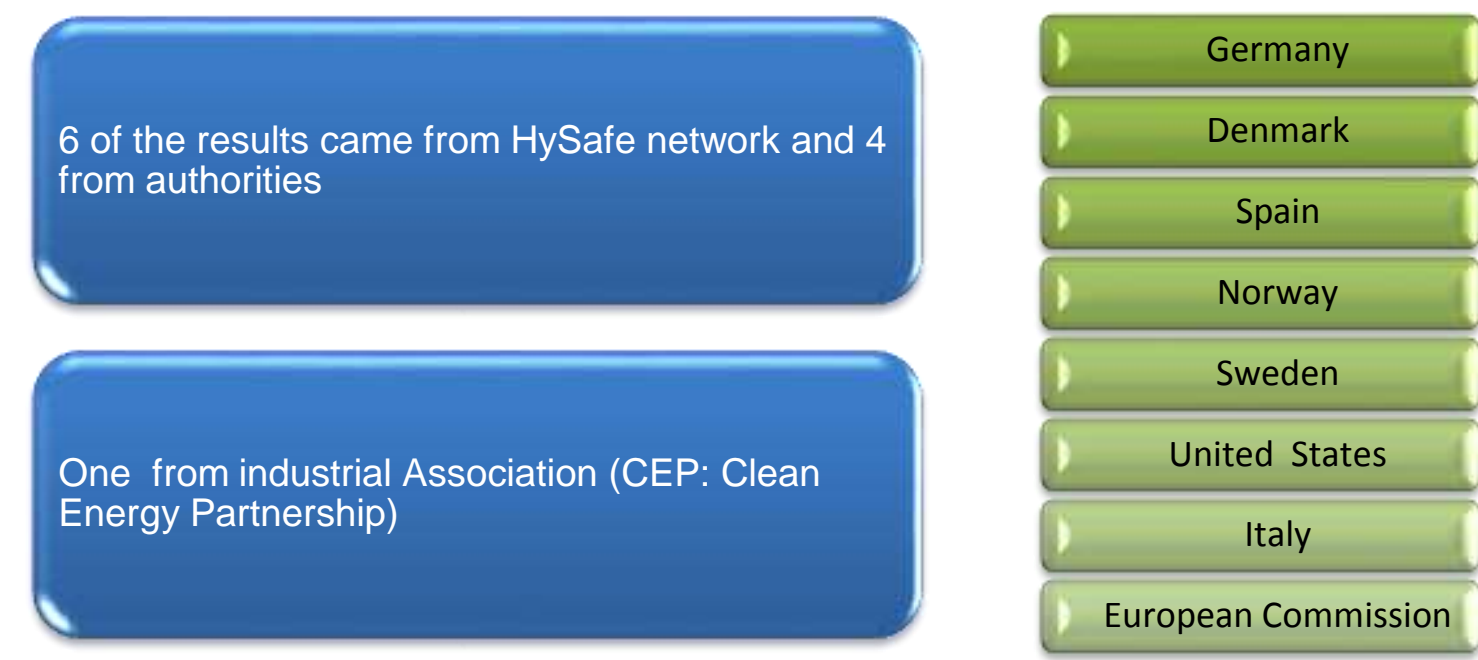

Figure 4 : Who answered to the questionnaire ${ }^{6}$ ?

\section{Main conclusions of the survey}

The following main conclusions were drawn from the analysis of the twelve received questionnaires:

- Apart from the case of Italy, no national regulation specific to hydrogen fuelling stations was mention by the respondents. In Italy, a decree ${ }^{7}$ published in 2006; specifies the requirements for fire prevention of such facilities.

- Some countries have no specific regulation but have their own technical guidelines. This is the case of Canada and Germany with the Canadian Hydrogen Installation Code $(\mathrm{CHIC})^{8}$ or the German Requirement for Hydrogen fuelling stations ${ }^{22}$;

- Such as technical specifications like ISO/TS $20100^{\circ}$ (see chapter 4.2 for additional comments) or international standards like ISO $17268^{10}$ are considered as references and applied in almost all countries. The U.S. based Society of Automotive Engineers (SAE International) also developed widely accepted standards that feed the ISO Standards and are mainly focused on the distribution devices and the interface with the vehicle; 
- The authorities in charge of controlling or permitting the hydrogen fuelling stations are very diverse and, depending on the country, may be a state authority or a private agency. For example, in Germany TÜV, which is a private organization, is responsible to control the installation before its operation;

- Several of reference documents recommend safety distances such as EIGA ${ }^{11}, \mathrm{CHIC}$, Italian decree but the most cited are the technical specification ISO/TS20100 and/or NFPA $55^{12}$ standards;

- Safety barriers to prevent fire, explosion and overpressure or protect against their effects are mainly inspired from best practices in industrial activities where handling hydrogen is usual. Specific safety barriers were developed for the distribution activity and the associated equipment such as hydrogen dispenser, its nozzle and the interface with the car.

- The 2014/94/UE directive on the deployment of alternative fuels infrastructure specifically mentions ISO/TS 20100, ISO 14687-2 and ISO 17268 as references for fuelling stations. The future fuelling stations should comply with their requirements.

The next chapters present a synthesis of the framework regulations and standards that were most frequently mentioned as references and of the main safety measures they promote.

\section{Regulatory and Legal Context}

Several regulations are applicable to fuelling stations without being specific to them. The European directives, such as ATEX, and those relative to pressurized equipment or standards relative to cryogenic tanks can be cited. These texts were identified, but were not in the scope of this study.

The study has been focused on specific regulation, codes and standards that deal with hydrogen fuelling stations in their whole or for certain components of them. Its particular context is a directive adopted by the European Parliament and the council on September $29^{\text {th }}$ in 2014.

\subsection{European Directive}

The directive 2014/94/UE was adopted for the development of an infrastructure for alternative fuels for member states of the European Union.

This directive:

- requires Member States to develop national policy frameworks for the market development of alternative fuels and their infrastructure;

- foresees the use or common technical specifications for recharging and fuelling stations;

- paves the way for setting up appropriate consumer information on alternative fuels, including a clear and sound price comparison methodology.

The European directive is an ambitious package of measures to ensure the build-up of alternative fuel stations across Europe with common standards for their design and use. 


\section{$\underline{\text { Content of directive }}$}

$1 /$ The directive imposes an appropriate number of hydrogen refuelling points, to ensure the circulation of hydrogen-powered vehicles.

2/ The directive refers to the following ISO standards and technical specifications while waiting for the publication of ad hoc EN standards:

- ISO/TS 20100 for the conformity of fuelling points and dispensing equipments;

- ISO 14687-2 for quality characteristics of hydrogen fuel;

- ISO 17268 for the conformity of vehicle refuelling connection devices.

- These three standards are mentioned in annex II of the Directive, Annex II can be modified through a delegated act process issued by the European Commission.

The European Community gave to CEN TC 268 WG 5 "specific hydrogen technologies applications" the mandate to prepare EN standards supporting this directive. The extension of CEN 268 was enacted during the meeting on June $16^{\text {th }} 2014$. This mandate concerns the adaptation of the above three standards. The deadline given in the mandate between EC and CEN to elaborate these standards, initially foreseen for the end of 2014 , was postponed to December $31^{\text {st }} 2016$.

3 / In addition, the directive requires clear information for consumers about the fuels that can be used by a vehicle, using standardized labelling of vehicles, at dealerships and on the recharging and refuelling points. It also aims at providing clear information to users to compare alternative fuel prices with conventional fuel prices. Moreover, Member States must ensure that information about the geographical location of publicly accessible recharging and refuelling points is made available in an open and non-discriminatory manner.

\section{Comments of European commission}

"Alternative fuels are a key to improving the security of energy supply, reducing the impact of transport on the environment and boosting EU competitiveness", said Commission VicePresident Siim Kallas, commissioner for transport. "With these new rules, the EU provides long-awaited legal certainty for companies to start investing, and the possibility for economies of scale. EU Member States requested flexibility in deploying the infrastructure. It is now up to them to develop the right national policy frameworks."13

Up to now, clean fuels have been held back by three main barriers: the high cost of vehicles, a low level of consumer acceptance, and the lack of recharging and refuelling stations. This is a vicious circle. With the new "directive for the deployment of the alternative fuels infrastructure", Member States will have to provide a minimum infrastructure for alternative fuels such as hydrogen, as well as common EU-wide standards for equipment needed and user information.

Overview of others texts

Beyond this cited directive and standards, the benchmark allowed the identification of other relevant texts. 
Figure 5 positions on a chronological axis the 13 identified texts applicable to hydrogen fuelling stations. It allows us to have a global vision of the evolution of the regulatory and normative context. We have included in this panorama guides conceived in the context of research projects that have served in the elaboration of references. 


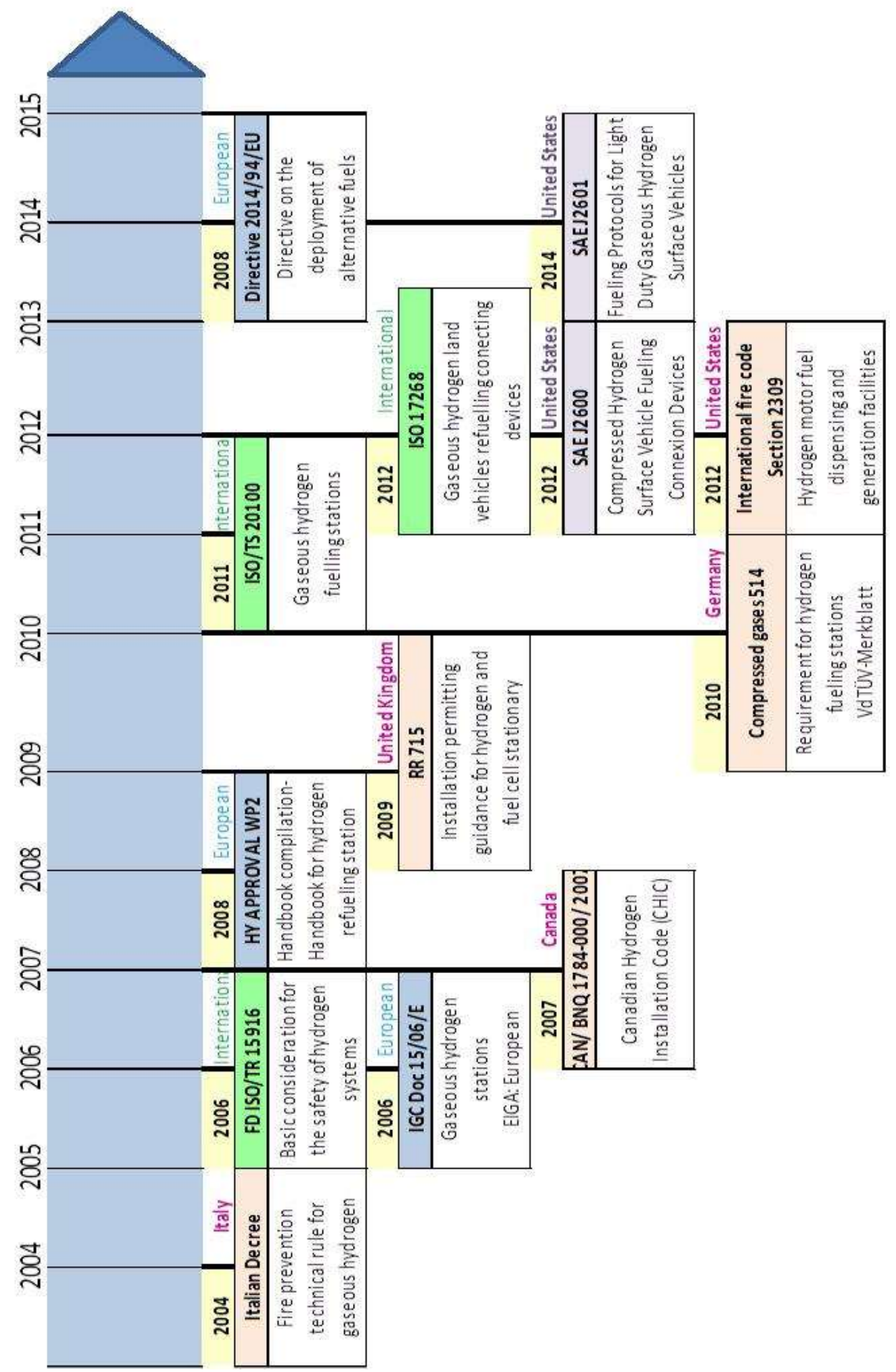

Figure 5: Chronological Presentation of the Regulatory and Normative Context 


\subsection{International Standards/technical recommendations}

\section{ISO/TS 20100}

Even if the directive foresees to include the technical specifications of ISO/ TS 20100 on the refuelling aspect, this standard specifies the characteristics for complete installation of a fuelling station public or not.

In 2011, the final version of the standard remained as a draft proposal as no consensus was obtained to pass it as international standard mainly due to a disagreement on the proposed safety distances in this draft. At the last plenary meeting of ISO 197 in December 2015 the ISO TS 20100 has been withdrawn and is revised by ISO TS 19880-1.

Due to the aforementioned disagreements, a new text, ISO 19880, is currently under progress in the TC197 WG24. Table 1 identifies the different working groups on ISO/AWI 19880. The TS 19880-1 will be soon published and an international standard IS 19880-1 is planned to be achieved before the end of 2016 and publish in early 2017 .

\begin{tabular}{|l|l|}
\hline Standard & Name of the Standard \\
\hline ISO/AWI 19880-1 & Gaseous Hydrogen Fuel - Fuelling Stations - Part 1: General Requirements \\
\hline ISO/AWI 19880-2 & Gaseous Hydrogen Fuel - Fuelling stations - Part 2: Distribution \\
\hline ISO/AWI 19880-3 & Gaseous Hydrogen Fuels - Fuelling stations - Part 3: Valves \\
\hline ISO/AWI 19880-4 & Gaseous Hydrogen Fuel - Fuelling stations - Part 4: Compressors \\
\hline ISO/AWI 19880-5 & Gaseous Hydrogen Fuel - Fuelling stations - Part 5: Piping \\
\hline ISO/AWI 19880-6 & Gaseous Hydrogen Fuel - Fuelling stations -Part 6: Fittings \\
\hline
\end{tabular}

Table 2: The current topics at ISO 197 level in relationship to the hydrogen fuelling station

\subsection{National Regulations}

There are few mandatory regulatory texts specific to hydrogen fuelling stations. The only text that imposes a regulation is an Italian decree written in 2004. It was an innovative text when it was published and has become difficult to apply with the current evolution of fuelling stations, particularly because it limits distribution pressure to 350 bar, whereas the standard for light vehicles is now 700 bar. Besides these identified texts new regulations are in preparation in France according to the Hydrogen indoor refuelling for forklifts and getting in obligation in $2016^{14}$. And also in Canada the Canadian Hydrogen Installation Code (CHIC) will get mandatory in future for hydrogen fuelling stations ${ }^{15}$. 


\subsection{Synthesis of applicable texts}

The figure below outlines the covering regulations, codes and standards in relation to the different parts of the installation and specifies the status of texts according to the legend below.

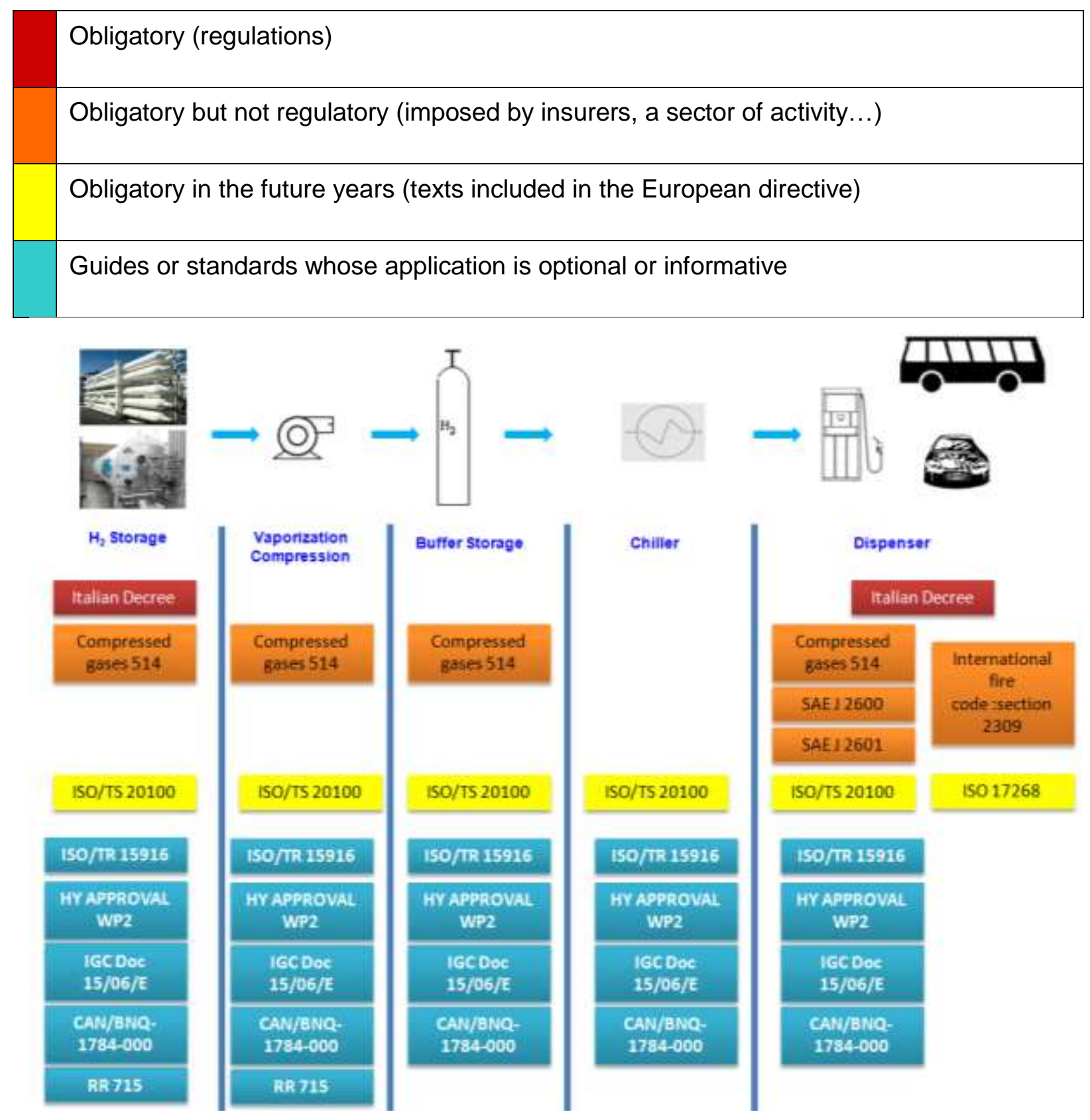

Figure 6: Thematic Presentation of Regulatory Texts 


\section{Presentation of Risk Control Measures}

\subsection{Description of analysis}

Safety measures were gathered in a benchmark (available on INERIS website ${ }^{16}$ ) issued from 12 documents, which also indicate what aspects they consider.

In the report, the prescriptions about different items were identified and compared. It is described here how the instructions are presented and the analysis realized. The measures are divided into three categories:

- Prescriptions relating to fuelling stations in general and equipment outside of the dispensing zone;

- Safety distances;

- Specific prescription for dispensing area.

In each chapter, the risk control measures are identified.

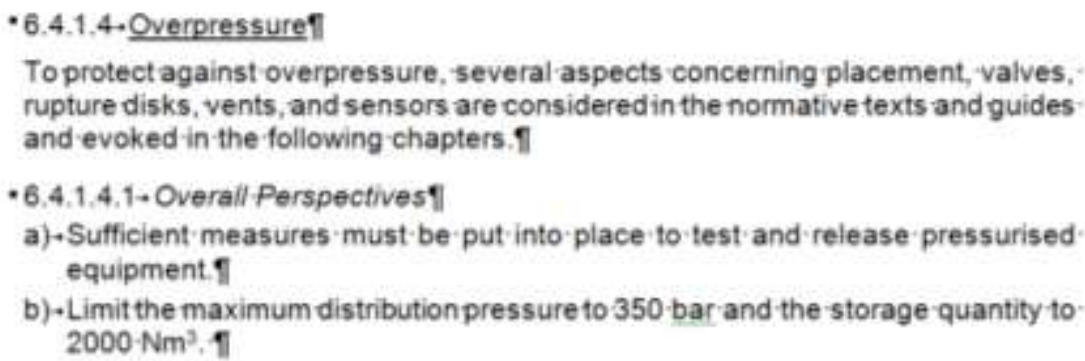

Figure 7: Example of numeration

The whole of the measures are then gathered together in a table allowing to make the link between the standards and the guides they come from. The sources are presented in their field of application: international, European, American, and national.

\begin{tabular}{|c|c|c|c|c|c|c|}
\hline - & \multicolumn{2}{|c|}{ Hydrogen ·Quality } & an & ba & $\mathrm{cat}$ & dat \\
\hline - & \multicolumn{6}{|c|}{ International-Application- $\square$} \\
\hline " & $\begin{array}{l}\text { Technical-Committeeף } \\
\text { ISO-Standarda }\end{array}$ & ISO/TS· $20100 a$ & $a$ & a & $a$ & $X^{a}$ \\
\hline - & \multicolumn{6}{|c|}{ European-Application- $\square$} \\
\hline " & $\begin{array}{l}\text { European-Commission } \cdot \uparrow \\
\text { Handbook }\end{array}$ & HY·APPROVAL·WP2 ${ }^{a}$ & $a$ & $a$ & $X a$ & $a$ \\
\hline$\cdot$ & EIGAD & IGC $\cdot$ Doc $\cdot 15 / 06 / E^{x}$ & $X a$ & $a$ & $a$ & $a$ \\
\hline " & \multicolumn{6}{|c|}{ National-Application } \\
\hline " & Germany & Compressed gases $514 x$ & a & $X a$ & $a$ & $a$ \\
\hline
\end{tabular}

Table 3: Example of a table 
A synthesis summarises the key points, identifying the measures taken up in several standards and highlighting the barriers included in the ISO standards.

\section{Key.points - II}

This chapter - treats the requirements concerning -measures to control the - risk - of overpressure. ๆ

A-first point is the obligation to install-valves and/or rupture disks in places where hydrogen gas can be trapped or in case of thermal dilatation. These devices must be dimensioned in relation to the function of the equipment /components present on the line and taking into account malfunctions of the installation. ๆ

Figure 8: Except of a synthesis 


\subsection{Synthesis of Risk Control Measures and Safety distances}

\section{Risk Control Measures}

It is impossible to do an exhaustive summary of the identified risk control measures in this paper. We can nevertheless highlight the main aspects covered by the consulted documents and some of the principal orientations for the various components of a hydrogen fuelling station.

\begin{tabular}{|c|c|c|c|c|c|c|c|c|c|c|c|}
\hline & & 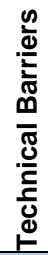 & 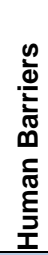 & 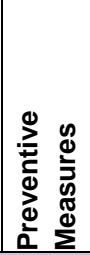 & 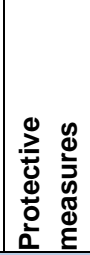 & 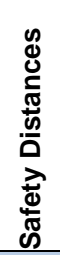 & 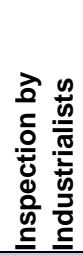 & 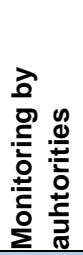 & $\begin{array}{l}\frac{0}{0} \\
\frac{0}{0} \\
\frac{c}{0} \\
\frac{d}{2} \\
\frac{5}{1}\end{array}$ & 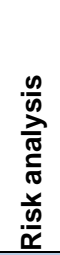 & 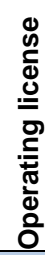 \\
\hline \multicolumn{12}{|c|}{ International Application } \\
\hline \multirow{3}{*}{$\begin{array}{l}\text { Technical } \\
\text { Committee } \\
\text { ISO Standard / } \\
\text { Technical } \\
\text { Specifications }\end{array}$} & FD ISO/TR $15916^{17}$ & $\mathbf{x}$ & $\mathbf{x}$ & $\mathbf{x}$ & $\mathbf{x}$ & & & & & & \\
\hline & ISO 17268 & $\mathbf{x}$ & $\mathbf{x}$ & $\mathbf{x}$ & $\mathbf{x}$ & & & & & & \\
\hline & ISO/TS 20100 & $\mathbf{x}$ & $\mathbf{x}$ & $\mathbf{x}$ & $\mathbf{x}$ & $\mathbf{x}$ & & & & & \\
\hline \multicolumn{12}{|c|}{ European Application } \\
\hline $\begin{array}{l}\text { Commission } \\
\text { European }\end{array}$ & $\begin{array}{l}\text { HY APPROVAL } \\
\text { WP2 }^{18}\end{array}$ & $\mathbf{x}$ & $\mathbf{x}$ & $\mathbf{x}$ & $\mathbf{x}$ & & $\mathbf{x}$ & $\mathbf{x}$ & $\mathbf{x}$ & $\mathbf{x}$ & $\mathbf{x}$ \\
\hline EIGA & IGC Doc 15/06/E & $\mathbf{x}$ & $\mathbf{x}$ & $\mathbf{x}$ & $\mathbf{x}$ & $\mathbf{x}$ & & & & & \\
\hline \multicolumn{12}{|c|}{ American Application } \\
\hline United States & NFPA 55 & & & & & $\mathbf{x}$ & & & & & \\
\hline United States & $\begin{array}{l}\text { International fire code: } \\
\text { section } 2309^{19}\end{array}$ & $\mathbf{x}$ & $\mathbf{x}$ & $\mathbf{x}$ & $\mathbf{x}$ & & & & & & \\
\hline SAE & SAE J $2600^{20}$ & $\mathbf{x}$ & $x$ & $\mathbf{x}$ & $\mathbf{x}$ & & & & & & \\
\hline SAE & SAE J $2601^{21}$ & $\mathbf{x}$ & $\mathbf{x}$ & $\mathbf{x}$ & $\mathbf{x}$ & & & & & & \\
\hline \multicolumn{12}{|c|}{ National Application } \\
\hline Germany & $\begin{array}{l}\text { Compressed gases } \\
514^{22}\end{array}$ & $\mathbf{x}$ & $\mathbf{x}$ & $\mathbf{x}$ & $\mathbf{x}$ & $\mathbf{x}$ & & & & & \\
\hline Canada & CAN/BNQ-1784-000 & $\mathbf{x}$ & $\mathbf{x}$ & $\mathbf{x}$ & $\mathbf{x}$ & $\mathbf{x}$ & $\mathbf{x}$ & & $\mathbf{x}$ & & $x$ \\
\hline Italy & FPTCGHRS & $x$ & $\mathbf{x}$ & $\mathbf{x}$ & $\mathbf{x}$ & $\mathbf{x}$ & & & & & \\
\hline United Kingdom & $\mathrm{RR} 715^{23}$ & $x$ & $\mathbf{x}$ & $\mathbf{x}$ & $\mathbf{x}$ & & & & $x$ & & $\mathbf{x}$ \\
\hline
\end{tabular}


Regarding unloading, storage, compression, cooling, the recommendations in the studied references are related to safety measures usually adopted for industrial sites handling hydrogen.

The goal is specifically to control the risks of hydrogen leaks and inflammation as well as overpressure. They often refer to the regulatory and standards framework associated with ATEX directives, pressurised equipment ...

Certain recommendations are more specifically linked to the properties of hydrogen. Thus is treated the risk of embrittlement or the necessity of avoiding confinement.

Finally, the refuelling zone is the object of particular attention that leads to a development of innovative and specifically adapted risk control measures for hydrogen distribution. For example, the fuelling nozzle is equipped with an anti-tear- off device, an emergency stop in case of a collision...

The distribution protocol is defined in a very precise manner with monitoring of key parameters (temperature, pressure...) and relies on a communication interface between the vehicle (specific 700 bar) and the distribution pump. The loading of the tank, the temperature, and the pressure are communicated and verified constantly by a regulation system that optimises the flow and automatically interrupts fuelling.

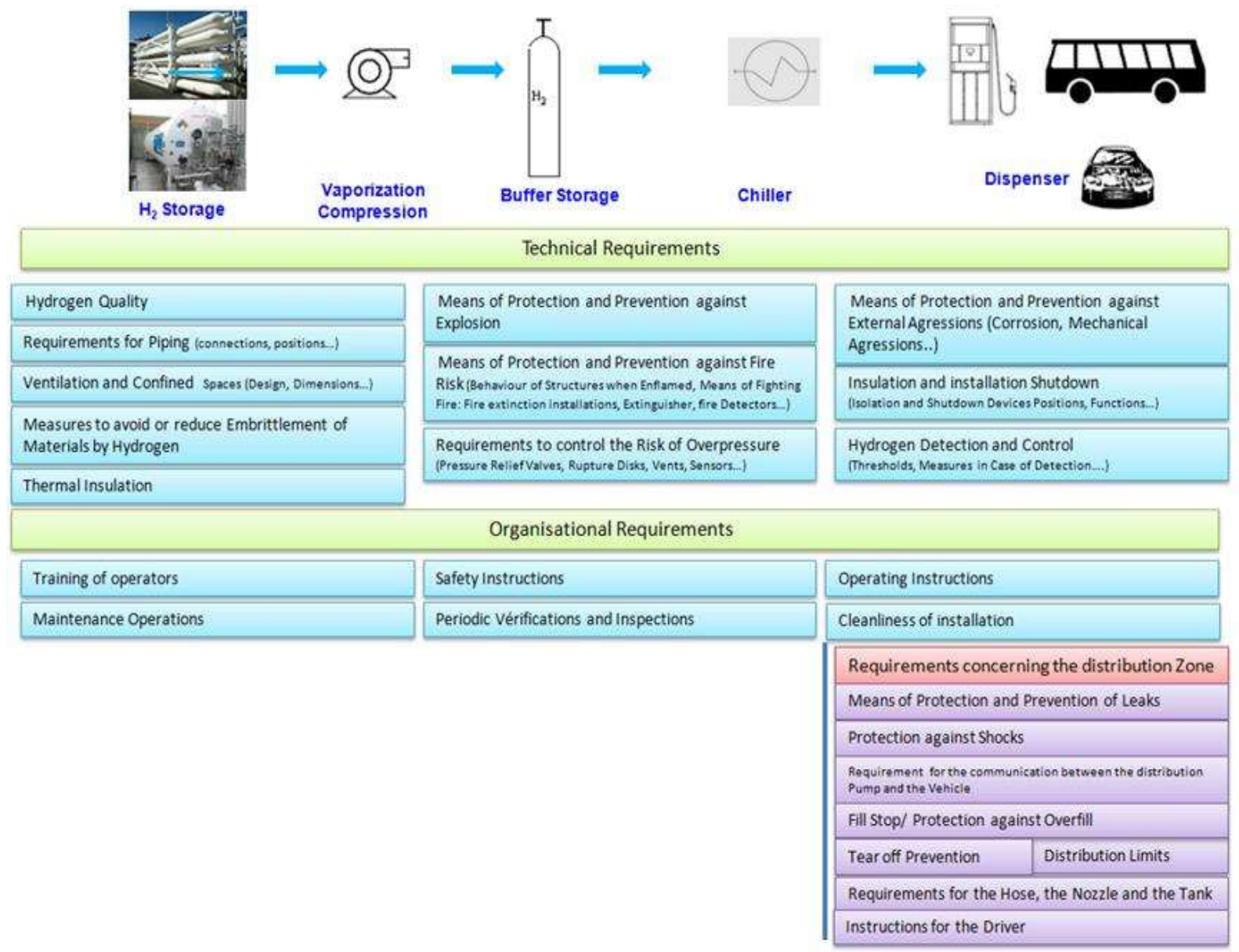

Figure 9: Synthesis of safety function for each part of fuelling station 


\section{Safety distances}

\section{Safety distances definition}

Several guidelines introduce internal and external safety distances regarding hydrogen fuelling station. But there is still a lack of consensus amongst the different countries on which safety distances to apply and on how to determine them. This lack of consensus prevented the adoption of the technical specification ISO/TS 20100 as a full standard. The disagreement was primarily between the United States and Europe. Europe validated the standard whereas the United States promoted larger distances such as described in NFPA standards.

\section{Comparison of NFPA and ISO Approaches for Evaluating Safety Distances}

The differences between safety distances proposed by ISO TS 20100 (International Standardization Organisation) and the NFPA 55 (National Fire Protection Association) were highlighted in the following two papers:

- comparison of NFPA and ISO approaches for evaluating separation distances by Jeffrey LaChance- Sandia National Laboratories- July 26, $2010^{24}$

- safety distances: comparison of the methodologies for their determination by M.Vanuzzo, M. Carcassi -Department of Mechanical, Nuclear and of Production Engineering, University of Pisa, Via Diotisalvi 2, Pisa 56126, Italy. ${ }^{25}$

Both organisations make a quantitative risk assessment:

- effect distances are based on the selection of hydrogen leak sizes;

- leak probability is evaluated according to different methods by integrating inflammation probability.

The safety distances between equipment and potential internal and external targets exposed to dangerous phenomena are thus based on risk acceptability thresholds. These thresholds are defined for these different targets (persons in the exterior, etc.).

A major difference between the NFPA and ISO is the choice of leak dimension. The NFPA always considers a release hole equal to $3 \%$ of the flow section. ISO uses smaller dimensions that vary according to the considered system type and that reach at the maximum $1.81 \%$ of the flow section. The NFPA also considers Flash Fire / VCE, unlike ISO.

Safety distances remain a subject on which different countries have not yet come to a consensus. The subject of safety distances is the object of the ISO draft standard 19880, which is in the process of being elaborated and which is projected to be finalised in the coming years. The standard will be certainly specific for Europe without consensus. 


\section{Conclusion}

This comparative study had the objective of identifying main regulations and best practices in various countries related to hydrogen fuelling stations, reviewing the safety barriers required for fuelling stations and identifying lessons learned on the technology in terms of safety.

So far, only Italy has adopted a national specific regulation on hydrogen fuelling stations. The other countries widely rely on existing international standards. The standardization framework is rapidly evolving in Europe pushed by the adoption of the 2014/94/UE directive on the deployment of alternative fuels infrastructure.

Some new regulations are in preparation like in France where a decree for indoor fuelling stations will get mandatory in 2016 or in Canada where the Canadian Hydrogen Installation Code will get mandatory for hydrogen fuelling stations in the future.

Based on this set of reference documents, among which, in particular, ISO/TS 20100, a series of risk control measures specific to fuelling stations were identified. Whereas safety of unloading, storage, compression and cooling is mostly achieved with safety barriers directly inspired from industrial best practices, specific safety measures apply to the distribution activity and devices.

Finally, safety distances are still the object of a disagreement between Europe and United states. They will be addressed in future standards with probably a limited regional application.

The whole study is published in a report available on INERIS website.

\section{Acknowledgements}

The authors would like to thank the French Ministry of Ecology, Energy Transport and Sustained Development and especially the General Directorate for Risk Prevention (DGPR) for the financial grant in the scope of the DRA-71 program. 


\section{References}

1 International Association on Hydrogen Safety; http://www.hysafe.info/

2 Directive 2014/94/EU of the European Parliament and of the Council of 22 October 2014 on the deployment of alternative fuels infrastructure Text with EEA relevance; http://eur-lex.europa.eu/legalcontent/EN/TXT/?uri=celex\%3A32014L0094

3 INERIS published a report on the topic hydrogen fueling stations benchmark on its website: https://www.google.fr/url?sa=t\&rct=j\&q=\&esrc=s\&source=web\&cd=1\&cad=rja\&uact=8\&ved=0ahUKEw jo5OCD46nKAhWB7BQKHWStAbUQFggfMAA\&url=http\%3A\%2F\%2Fwww.ineris.fr\%2Fcentredoc\%2 Fdra-71-rapport-benchmark-station-service-hydrogene--diffusion-1-

1427110132.pdf\&usg=AFQjCNGIdQeyNYigsO_TUMKEs1DvwJbMOw\&sig2=RihmiW_vbu052E4sEus MOw\&bvm=bv.111677986,d.d24

${ }^{4}$ Statistical analysis based on www.netinform.net-

${ }_{5}^{5}$ ISO/CD 19884 Gaseous hydrogen - Cylinders and tubes for stationary storage: Standard under development, specifies the requirements for assessing cylinders, tubes, and other pressure vessels.

6 The Clean Energy Partnership (CEP) was established in December 2002 as a joint initiative of government and industry lead-managed by the German Ministry of Transport and Industry. Its aim is to test the suitability of hydrogen as a fuel. Since 2008, the CEP has been a lighthouse project of the National Hydrogen and Fuel Cell Technology Innovation Programme (NIP), implemented by NOW (National Organisation for Hydrogen and Fuel Cell Technology) (http://www.now-gmbh.de/de/). Industry partners - Air Liquide, Bohlen \& Doyen, BMW, Daimler, EnBW, Ford, GM/Opel, Hamburger Hochbahn, Honda, Hyundai, Linde, OMV, Shell, Siemens, Stuttgarter Strassenbahnen SSB, Total, Toyota, Volkswagen and Westfalen - are involved in the CEP. Experts from these companies work together in councils that transcend branch boundaries, to pave the way for the market launch of hydrogen vehicles

7 D.M. 31st of August 2006, Fire prevention technical rule for gaseous hydrogen refuelling stations (O.J. of the Italian Republic n. 213 - 13th of September 2006):

${ }^{8}$ Canadian Hydrogen Installation Code : Code to establish the installation requirements for hydrogen generating equipment, hydrogen utilization equipment, hydrogen dispensing equipment, hydrogen storage containers, hydrogen piping systems and their related accessories. https://www.scc.ca/en/standards/work-programs/bnq/canadian-hydrogen-installation-code

${ }^{9}$ ISO/TS 20100:2008 specify the characteristics of outdoor public and non-public fuelling stations that dispense gaseous hydrogen used as fuel onboard land vehicles of all types. This reference is revised by ISO/DTR $19880-1$

10 ISO 17268:2012 defines the design, safety and operation characteristics of gaseous hydrogen land vehicle (GHLV) refuelling connectors consisting of, as applicable, a receptacle and a protective cap (mounted on vehicle), and a nozzle

11 GASEOUS HYDROGEN STATIONS, IGC Doc 15/06/E, Revision of Doc 15/96 and Doc 15/05, EUROPEAN INDUSTRIAL GASES ASSOCIATION AISBL

12 NFPA 55: COMPRESSED GASES AND CRYOGENIC FLUIDS CODE, 2013 edition, National Fire Protection Association, NFPA 55 facilitates protection from physiological, over-pressurization, explosive, and flammability hazards associated with compressed gases and cryogenic fluids.

13 Clean fuels for transport: Member States now obliged to ensure minimum coverage of refuelling points for EU-wide mobility; http://europa.eu/rapid/press-release_IP-14-1053_en.htm

${ }_{14}$ Decree of on general requirements for plants employing hydrogen gas in a classified facility for the protection of environment for feeding hydrogen gas trolleys when the amount Hydrogen present within the institution is the reporting regime for heading No. 4715; Source: http://www.legifrance.gouv.fr/affichTexte.do?cidTexte=JORFTEXT000031672427

15 Communication with Dr. Andrei V. Tchouvelev leader of the Canadian Hydrogen Safety Program and Chair of ISO/TC 197 Hydrogen technologies.

16 INERIS published a report on the topic hydrogen fueling stations benchmark on its website: https://www.google.fr/url?sa=t\&rct=j\&q=\&esrc=s\&source=web\&cd=1\&cad=rja\&uact=8\&ved=0ahUKEw jo5OCD46nKAhWB7BQKHWStAbUQFggfMAA\&url=http\%3A\%2F\%2Fwww.ineris.fr\%2Fcentredoc\%2 Fdra-71-rapport-benchmark-station-service-hydrogene--diffusion-1-

1427110132.pdf\&usg=AFQjCNGIdQeyNYigsO_TUMKEs1DvwJbMOw\&sig2=RihmiW_vbu052E4sEus MOw\&bvm=bv.111677986,d.d24 
17 FD ISO/TR 15916:2006 Basic Considerations For The Safety Of Hydrogen System: provides guidelines for the use of hydrogen in its gaseous and liquid forms. It identifies the basic safety concerns and risks, and describes the properties of hydrogen that are relevant to safety. Detailed safety requirements associated with specific hydrogen applications are treated in separate International Standards

18 WP2 HyApproval - Handbook for Hydrogen Refuelling Station Approval: http://www.hyapproval.org/Publications/Deliverables_and_Reports/HyApproval_D2_2-

Appendix_I_V2.0.pdf

19 International Fire Code: https://law.resource.org/pub/us/code/ibr/icc.ifc.2009.pdf

20 SAE J2600 Compressed Hydrogen Surface Vehicle Fueling Connection Devices; Standard applies to the design and testing of Compressed Hydrogen Surface Vehicle (CHSV) fueling connectors, nozzles, and receptacles. Connectors, nozzles, and receptacles must meet all SAE J2600 requirements and pass all SAE J2600 testing to be considered as SAE J2600 compliant.

21 SAE J 2601Fueling Protocols for Light Duty Gaseous Hydrogen Surface Vehicles ; Standard establishes safety limits and performance requirements for gaseous hydrogen fuel dispensers. The criteria include maximum fuel temperature at the dispenser nozzle, the maximum fuel flow rate, the maximum rate of pressure increase and other performance criteria based on the cooling capability of the station's dispenser.

22 Compressed gases 514, Requirements for hydrogen fueling stations, 2010 Technical specification sheets (VdTÜV-Merkblätter).

23 RR715 - Installation permitting guidance for hydrogen and fuel cell stationary applications: UK version: http://www.hse.gov.uk/research/rrhtm/rr715.htm

24 COMPARISON OF NFPA AND ISO APPROACHES FOR EVALUATING SEPARATION DISTANCES, Jeffrey LaChance, Sandia National Laboratories, July 26, 2010 http://www.hydrogenandfuelcellsafety.info/2010/aug/separationDistances.pdf

25 SAFETY DISTANCES: COMPARISON OF THE METODOLOGIESFOR THEIR DETERMINATION M. Vanuzzo, M. Carcassi: http://conference.ing.unipi.it/ichs2011/presentations/121_Vanuzzo\%20M.ppt 